\title{
EFFECTS OF RUSSIA'S WTO ACCESSION ON AGRICULTURAL TRADE AND PRODUCTION
}

\author{
Natasa Stanojevic ${ }^{1}$ \\ Faculty of International Economics, Belgrade, Serbia ${ }^{2}$
}

\begin{abstract}
The paper explores the benefits and challenges facing agriculture as the most sensitive sector of the Russian economy after a two years long membership in the WTO. The key parts of the paper investigate current effects that the new trade rules have brought to Russian agriculture, and subsequently to its major trading partners. It has been found that both groups of effects are very different, and in some segments totally opposite to forecasts and expectations. The sectors that have had the best chance to benefit from trade liberalization show a significant drop in exports, while the weakest ones record a growth in production. The research seeks to explain how the expected negative effects have been avoided, which would provide useful lessons for the future WTO members. The unexpected results, as research shows, come from the measures taken by Russia prior to admission to the WTO, then the advantages it agreed on during the negotiations and finally practical moves during the implementation of the new rules.

Key words: Russia, agriculture, WTO, subsidies, export, import
\end{abstract}

\section{INTRODUCTION}

A record-long process of Russia's accession to the World Trade Organization (WTO) over almost two decades has been attracting international attention. Scientific analyses and expert evaluations differ both in terms of the benefits and challenges that the accession to the WTO would bring to Russia, as well as the potential effects on other economies and world regions, given the size of the Russian economy and its regained political power.

The importance of the accession to this most influential multilateral organization, which sets the rules of international trade and controls their implementation, should not be additionally underlined. However, numerous limitations that these rules impose on the economies of member countries, as a rule affect their most vulnerable sectors. During the entire period of accession negotiations, the weakest sector of the Russian economy was agriculture. The forecasts of Russian and foreign scientific circles and organizations relating to the future of individual segments of the Russian agriculture upon accepting the rules imposed by the WTO are numerous, though not essentially different.

\footnotetext{
${ }^{1}$ nstanojevic@megatrend.edu.rs

${ }^{2}$ The paper is a part of research on the Ministry of Science project: Enhancing public policies in Serbia as a function of the improvement of social security of citizens and sustainable economic development, III47004.
}

Vol. 16, бpoj 3/2014, cmp. 93-109 
Since the formal accession of Russia to WTO in August 2012 enough time has passed to make the first effects visible. The aim of this study is to determine precisely what changes in the trade of agriculture products Russia has accepted by joining the WTO, in what extent it applies them, what (measurable) effects some groups of limitations have on various segments of Russian agriculture, as well as on the agriculture of its major trading partners. Insights into the latest key indicators of individual sectors of the Russian agriculture lead to the assumption that the effects of the WTO accession are significantly different from the predicted ones.

\section{THE CONDITION AND TRENDS OF AGRICULTURE IN RUSSIA}

After the collapse of the Soviet Union Russian agricultural production suffered severe consequences of transition. During the 90s agriculture was sinking deeper and deeper. According to FAOSTAT data (Food and Agriculture Organization of the UN Statistics), during the nineties Russia had a negative growth of agricultural and food production by $-0.45 \%$ and $-0.42 \%$ respectively. The big drought in 1998-1999 and the economic crisis in 1998 led to the situation in which Russia was forced to accept humanitarian aid.

A slow recovery of agriculture began after 1998, but does not apply to all segments of agriculture. For example, meat production in Russia was constantly falling until 2000. After 2000 the depreciation of the ruble took place, grain production increased, the government increased the budget to support livestock and introduced tariff protection. In the process of Russian rapprochement to the WTO rules, especially after the great financial crisis, the Russian government had to allocate a part of the revenue for economic reforms. It is exactly the agriculture sector that had the greatest benefits. In the period 2001-2006, the entire agriculture achieved a slight increase of $1.42 \%$ annually on average (FAO). In 2005 total agricultural production reached only $75 \%$ of the level in 1990, but this represented a significant increase compared to $30 \%$ in 1998. From 2006 agricultural production started increasing constantly. From 2006 until 2011 the growth was 2,68\% for agricultural production and 2,64\% (FAOSTAT) for food production.

Today, Russia's agriculture has a global significance again. In some industries production has a significant share in the world production, while Russian trade in agricultural products, especially imports, are of great importance for many economies around the world. 
The main crops in Russia are wheat, sugar beet, sunflower, potato and flax. In the production of cereals and legumes Russia is ranked fifth in the world (2012). The annual wheat production in Russia is about 40 million tons and occupies an important place in world production (6-8 \%) and exports (about $10 \%$ ) Barley, the second in gross yields after wheat, is largely used as animal feed and for the production of beer. The annual production is around 16 million tons, and represents about $12 \%$ of world production and about $14 \%$ of world exports (FAO, 2012).In the production of sunflower Russia is also one of the leading countries of the world. In recent years, the export of sunflower oil has reached record proportions.

Animal husbandry accounts for about $60 \%$ of gross agricultural production. It is an important supplier of the industries of milk, meat and wool. Cattle are the most common domestic animals, followed by sheep and goats. Until recently Russia used to produce very little poultry and frozen chicken was one of the major import items of Russia. Since 2012 the animal production has recorded a significant growth. The biggest rise has been recorded in the poultry and pigs, while in contrast to that, the production of cattle dairy products decreased by as much as $19 \%$ between the 2011 and 2012 (MLA Market Information data).

A few years before joining the World Trade Organization, pig breeding became one of the fastest growing sectors of the Russian economy, which was able to meet about $70 \%$ of domestic demand.

Russian federation joined the WTO with a significantly stronger agriculture than the one with which it had began negotiations. It acted in accordance with the recommendations of Russian analysts that only a relatively strong economy can benefit from joining the WTO. Russian economy as a whole at the time of accession to the WTO was relatively strong, but the question is whether agriculture as its most vulnerable sector is capable of withstanding global competition.

\section{THE PROCESS OF RUSSIA'S ACCESSION TO THE WTO}

The WTO (World Trade Organization) is an international economic organization which has great significance in promoting the liberal world trade and control of trade in goods and services of member countries. The model of liberal international trade provided by the WTO implies that member states renounce sovereignty in the conduct of foreign policy, and in return receive benefits resulting from membership in the organization.

The organization itself does not impose specific requirements for accession, but its members do. Only when they give their consent, the 
candidate may become a new member of the WTO. Therefore, each accession process is unique. The whole process takes about five years on average, but there are different cases.

Russia applied for membership in 1993, and its accession to the WTO turned out to be not only a long, but also an extremely complex process. After presenting the memorandum, the Russian group for technical issues had to answer 3500 questions raised by other WTO members, and for that reason the negotiations effectively started only in 1998.

The process of Russia's accession to the WTO was extremely complicated also due to certain specific circumstances. The most important obstacle to achieving the preconditions for the membership in the WTO involved activities of Russian protectionist lobbies. Despite pressure to liberalize economy, Putin's entire second term was marked by a new policy of import substitution, state interventions and protectionism.

Apart from that, the formation of the Customs Union of Russia, Kazakhstan and Belarus also complicated Russia's accession to this organization, and consequently the trade liberalization between the EU countries and Russia. Prior to joining the WTO, Russia applied a number of regulatory measures in the field of foreign trade, which included tariff and non-tariff measures. One of the most important non-tariff measures was to coordinate the planned quotas for imports of meat, milk and sugar between Russia and Belarus, as one of its most important trading partners. Measures which should also be pointed out are those related to the restriction of imports from the countries outside the CIS. These measures included increasing tariff quotas on meat imports, as well as the introduction of periodic duties on import of raw sugar.

Protection of intellectual property rights was a key issue in bilateral negotiations between Russia and the United States, after which in November 2006 Russia officially committed to fighting against piracy, closing down websites that illegally distributed music and other copyright-protected material, and passing appropriate laws to prevent further abuse, and so on.

Another specific circumstance involves the Russian-Georgian disagreements on how to provide adequate control of the borders of Abkhazia and South Ossetia.

In the aftermath of the global financial crisis, the fact that Russia was the only G-20 country outside the WTO represented a huge burden, and an indication that its economic model could experience a breakdown at one point. Therefore, the intensified negotiations and agreed to significant restrictions and obligations imposed by the rules of this organization. Its membership was granted in 2011, after 18 years of 
negotiations, and in August 2012 it finally became a full member of the WTO. With this act, the last of the world's great economic powers joined to the organization.

\section{RUSSIAN OBLIGATIONS IN THE FIELD OF AGRICULTURE UNDERTAKEN WITH THE WTO MEMBERSHIP}

By joining the World Trade organization Russia has had to accept the discipline and numerous rules. In previous years Russia has partly prepared to join the WTO in terms of many regulations, but there are still significant economic and trade reforms ahead of it.

A fundamental change is related to the inability to impose restrictions unilaterally when dealing with other members of the organization. Thus, Russia will not be able to arbitrarily raise tariff rates on imports or exports of sensitive products, which it has often done so far (Cooper, 2012, p. 13). The first step, which has already been undertaken in Russia, is the adjustment of tariff rates. Import duties in Russia decreased by $10 \%$ to an average of $7.8 \%$.

In agriculture, the obligations that the WTO members must fulfill are related to three areas: domestic support, market access and export subsidies.

1. Domestic support

The issue of state support for agriculture in Russia has always been of great importance, so that in the negotiations on the WTO accession this issue was also high on the agenda priorities of Russian negotiators. In the negotiations Russia managed to achieve much better conditions related to domestic support to agriculture than other member states, i.e. to agree on the terms that considerably differ from the standards of the World Trade Organization.

Namely, future WTO members must coordinate the amount of budgetary support for agriculture with an average budget support of other members at least three years prior to accession. However, Russia adopted a national program for agricultural development for the period up to 2020 which provides for much higher budgetary support to agriculture than the WTO rules allow, and this program remained in force after the accession to the WTO. Russian negotiators mainly used significant opportunities provided by the measures from the so-called 'Green box'. These are the measures the value of which is not limited in the WTO, and the mechanisms for such support are: subsidies for soil cultivation, the seed procurement, the construction of new facilities, the installations for energy savings, the development of logistics and infrastructure in rural areas. These measures are exempt from various restrictions because they 
serve as an incentive to improve the efficiency of agricultural production, create a long-term perspective, while direct subsidies are provided only as an emergency measure.

The WTO also provides for certain state support for agriculture beyond the 'Green box'. One of the outcomes of the negotiations process is the determined value of the maximum allowable level of state support for agriculture of 9 billion dollars in 2012-2013, which will subsequently be decreased to $\$ 4.4$ billion in 2018 (WTO). These funds may be used for reimbursement of certain farmers for fuel, low rates of 'agricultural' loans, etc..

However, joining the WTO will still lead to changes in the structure of state support to Russian agriculture. During the transition period, from the date of accession until December 31, 2017, it is required from RF that the funds set aside to support production industries should not exceed $30 \%$ compared to the funds supporting non-manufacturing industries.

\section{Market access}

Providing free access to the market of agricultural and food products for other WTO members is one of the most important obligations. The average tariff rate that applies to agricultural and food products in Russia should be $10.8 \%$ instead the previous $13.2 \%$ (WTO). For some products Russia had to agree to reduce tariffs to different extents.

The greatest reduction in tariffs was in cereals, meat and sugar, dairy products and edible oils. According to the WTO, the average duties after full implementation of the agreement will be:

- $14.9 \%$ for dairy products (as opposed to previous 19.8\%)

- $10 \%$ for cereals (as opposed to previous $15.1 \%$ )

- $7.1 \%$ for fats and oils (as opposed to previous 9.0\%)

The reduction of tariff rates has different impact depending on the product that the reduction applies to. A product that is the most sensitive to changes in Russia is sugar. During the accession negotiations it was agreed that Russia reduce the rate of fluctuating tariffs on sugar imports if its average price should fall below $\$ 100$ per ton. In addition, Russia pledged to use a specific range of the price of sugar for the entire calendar year. Earlier two scales were used - the major and the seasonal one. Now these two scales are replaced by the one that is valid throughout the year, and includes substantially lower prices.

The meat industry, which is extremely sensitive to competition from imports in Russia, had an extremely high level of tariff protection. In accordance with the WTO rules, the tariff rates on the import of poultry 
and livestock were reduced from $40 \%$ to $5 \%$, on the import of meat products from $25 \%$ to $15 \%$, while tariff rates on pork were lifted.

On imports of beef, pork, poultry and whey tariff quotas will be applied. An important achievement of Russia in the negotiations is that it has maintained the same volume of quotas for poultry and beef. Russia will control the import of poultry and beef for an indefinite period, and the import of pork until 2020. Imports within the quota will have lower rates, while higher tariff rates will be applied to products outside the prescribed quota. Thus, the following tariff rates are provided within the products subject to the quota system (WTO):

- $15 \%$ for beef, (55\% above the quota),

- zero for pork (65\% above the quota). Tariff rates within the quota for pork will be replaced by a rate of $25 \%$ from January 1, 2020,

- $25 \%$ ( $80 \%$ above the quota) for some selected poultry products,

- $10 \%$ (and 15\%) for whey products.

Market access to other agricultural and food products will also become much more liberal. Import duties on wine have been reduced from $20 \%$ to $12.5 \%$, while import duties on fruit will be reduced by more than a half compared to the level from 2011.

\section{Export subsidies}

The World Trade Organization basically does not allow export subsidies. To become a full member, Russia has had to commit to abolish export subsidies on all agricultural and food products.

A significant part of the negotiations was dedicated to sanitary and phytosanitary regime of Russia. It took the obligation that, from the date of accession, all measures of the sanitary and phytosanitary system would be developed in accordance with the WTO Agreement.

Upon entering the WTO Russia committed to apply export bans and restrictions only in the case of critical shortage of food in the country; those bans would be only of temporary character. Russia is required to report any changes to the WTO Committee on Agriculture in due course, which will help the developing countries to effectively respond to such moves.

\section{THE EXPECTED AND REALIZED EFFECTS ON RUSSIAN AGRICULTURE}

The positive effects of the accession to the WTO for Russian economy are expected in several segments. It is believed that this adjustment will improve business climate, attract foreign investment to Russia, modernize Russian economy and create more business opportunities for Russian companies. Mandatory measures of sanitary and 
phytosanitary system should enable Russia to realize a better cooperation with other countries and to make progress in the field of food safety, the area in which it has largely lagged behind other countries.

Russian consumers should have most benefits of the WTO accession because of the possible fall of living expenses as a result of the trade barriers lifting. The cheapening not only of imported goods and services is possible, but also of domestic items, especially those in the production of which imported raw materials are used.

These assumptions are common to almost all analysts, scientists and experts, both Russian and foreign.

What the WTO anticipates as a positive effect, although the member states rarely agree with it, concerns the transformation of the state support for agriculture. Reduction and even elimination of state support should allow the abandonment of the usual bad practice of subsidizing interest on loans and prevent the possibility of taking loans for fictional business plans. This transformation should also be a new impetus to the development of production.

Some authors have had positive forecasts in terms of the increase of export of certain agricultural products, namely cereals. According to the assessment of a group of authors from the University of St. Petersburg (ITC 2012, p. 9), Russia, as a major exporter of agricultural products such as wheat and barley, should benefit from this membership. According to them, the improvement of sanitary measures and the very WTO membership should lead to a slight increase in exports; the export of Russian grain is therefore anticipated to be about 25 million tons, while the total agricultural export is expected to increase from $15 \%$ to $17 \%$.

On the other hand, negative expectations were more numerous. Throughout the whole negotiation process, there was a lobby in RF that opposed the accession to the WTO, which to some extent influenced the record length of the process. Their main argument is that a young economy like the Russian at the time must first become strong enough and protect itself before it becomes ready to get out in a highly competitive global market. Russian Chamber of Commerce feared the possibility that the arrival of foreign products with a low price could be disastrous for domestic industry, the agricultural sector feared reduced subsidies, while the services sector feared the danger of tighter control of intellectual property and the prohibition of piracy, which at the time was deeply rooted in the Russian society.

The experience of other post-Soviet economies with the membership in the WTO in the years that followed only reinforced these attitudes, while negative expectations were also supported by the crisis in 
the global market, which increased the risk associated with the commitments that Russia had undertaken.

All forecasts agreed (ITC 2012, Global Council, Erokin and Ivolga 2013, Kiselev and Abstract Vision 2012) that, in response to the demand of domestic consumers, imports would outstrip domestic production, while imports from Europe and America would significantly increase, particularly of food products. Russian manufacturers, as well as experts gave especially pessimistic forecasts. Russian President Vladimir Putin also repeatedly pointed out that Russia, after entering the WTO, faced increased risks, especially in terms of the reduction of import duties on certain goods.

In addition, negative effects were expected due to reduced subsidies and protective measures of the state. Since many farms were dependent on government assistance, the fastest and most dramatic negative effects of the WTO membership were expected exactly in agriculture.

The most serious consequences of the WTO accession were expected in the livestock sector, especially pork production. Although Russia experienced growth in the production of meat, the living standard also kept growing, as well as the domestic demand, which further increased the import of meat from developing countries. That is why Russian Federation is still heavily dependent on imports of livestock products. It was reasonable to expect, and the predictions pointed that way, that due to the decrease of duty on livestock imports, most manufacturers would not survive the blow of competition, and this sector would experience the most severe impact of liberalization of imports (Global counsel, 2013). The forecasts of Russian trade unions representatives went as high as to predict three times higher production until 2020 (Bloomberg 2012), particularly in pig farming, in which quotas were completely lifted.

On entering the WTO, already by the end of 2012, the import of pork significantly increased indeed as predicted, to almost a record 750 000 tones (Karlova, N. 2013, p39). However, a year after the accession to the WTO the import of meat, especially pork fell noticeably. The import of pork fell from 1070 metric tons in 2012, to 900MT (USDA) in 2013, which is a reduction of more than $10 \%$. The import of pigs dropped drastically, from 782000 heads in 2011 to 334000 in 2012, and then to only 85,000 in the 2013 (USDA). The import of cattle is also in a slight decline. The total import of fresh and frozen pork and beef in 2013 was lower by $14.2 \%$, of poultry by $7.5 \%$, and of fish by $3.5 \%$ (Russian Federal State Statistics Service). 
Completely unexpected decrease in imports is the result of the cancellation of the preferential arrangements of the Customs Union with developing countries, particularly Brazil, from which RF had huge imports, and on the other hand, of great restrictions imposed by RF on the countries of North and Latin America and the European Union on the pretext of sanitary protection, which will be discussed later.

There is no doubt that Russia is concerned about food safety, but also that it uses such issues in order to protect its economic interests, fighting for self-sufficiency in food production.

On the other hand, Russia would not be able to prohibit the import of agricultural products if it could not meet the domestic demand out of its own production. For the relative self-sufficiency, regardless of the significant growth in recent years, Russian agriculture still needs the state support. Due to the WTO rules it has been greatly reduced, but Russia still allocates significant funds out of the so-called 'Green box', which has already been mentioned. In July 2012 Russia adopted A Program of Agricultural Development for the period 2013-2020 (Vassilieva Y. 2012) according to which the $\$ 76$ billion support for agriculture was planned over this period, whereby no sub-program conflicted with the WTO rules, and all grounds for agricultural finance could be explained under the provisions of the 'Green box'. We underline that the program for the previous 2008-2012 period provided $\$ 37$ billion, i.e. two times less than it was planned for the future. Livestock breeding is still the top priority.

The reduction of import already has very positive effects on the production of livestock in Russia, which in 2012 made an unexpected increase of $3.4 \%$ to 2.4 billion tons (Karlova N. 2013, 40). The trend continued in 2013, and large increase in production was achieved especially by corporate farms, where already in the first half of the year 257.4 tons more was produced than in 2012. (Russian Federal State Statistics Service).

In the sector of dairy products the situation is far worse. Already the beginning of 2013 saw a drop in prices by $3-5 \%$ as a consequence of increased imports by an average of $20 \%$, while in some product categories imports increased by as much as 33\% (Global Counsel 2013).

The predictions regarding negative consequences for farming were unfounded up to some extent, but the positive expectations in terms of production and exports of grain were also unrealistic. It is only the production of corn that achieved significant success, while the export of wheat and barley, as well as barley production has declined since the WTO accession.

Wheat exports amounted to about 21.6 billion metric tons in the year prior to admission of Russia to the WTO. It was almost halved to 
11.3 billion already in the first year of $2012 / 13$, only to increase slightly to 16.5 billion in $2013 / 14$, which is still significantly lower than before the implementation of the new rules (Table 1). A similar ratio is seen with the export of barley, which is the second most important cereal in Russia.

Table 1.: Russian production of wheat and barley (000 MT)

\begin{tabular}{|c||c|c||c||c|c|}
\hline & $\mathbf{2 0 0 9 / 1 0}$ & $\mathbf{2 0 1 0 / 1 1}$ & $\mathbf{2 0 1 1 / 1 2}$ & $\mathbf{2 0 1 2 / 1 3}$ & $\mathbf{2 0 1 3} / \mathbf{1 4}$ \\
\hline $\begin{array}{c}\text { Wheat } \\
\text { production }\end{array}$ & 61770 & 41508 & 56240 & 37720 & 52100 \\
\hline $\begin{array}{c}\text { Wheat } \\
\text { exports }\end{array}$ & 18556 & 3983 & 21627 & 11289 & 16500 \\
\hline $\begin{array}{c}\text { Barley } \\
\text { production }\end{array}$ & 17881 & 8350 & 16938 & 13952 & 15000 \\
\hline $\begin{array}{c}\text { Barley } \\
\text { exports }\end{array}$ & 2086 & 969 & 3668 & 2366 & 2500 \\
\hline
\end{tabular}

Source: The author according to USDA 2014 data

Exports of other grains, oats and rye are on the slight increase or stagnation in Russia and Ukraine, but this trend can be traced back for a decade (USDA 2014) and is not related to the WTO accession.

After the crisis in Crimea, there was no negative effects to the food export. According to Russian Statistics Seervice (2014) exports of food products in the commodity composition of exports in January-July 2014 amounted to 2.7 (in January-July 2013 - 2.0\%). In comparison with January-July 2013 export value of these goods increased by $39.1 \%$. Exports of food products in CIS countries, in the commodity composition of exports in January-July 2014 amounted to 7.8\% (in January-July 2013 - 6.1\%). In comparison with January-July 2013 export value of these products increased by $26.8 \%$. Increased volume of exports of poultry meat by $15.2 \%$, cheese and cottage cheese - $5.0 \%$, wheat $-27.6 \%$, vegetable oil - by $31.5 \%$.

At the beginning of August 2014, Russia banned imports of a wide range of U.S. and European foods in response to Western sanctions. The products subject to the one-year ban are beef, pork, poultry, fish, fruit, vegetables, cheese, milk and other dairy products from the U.S., Canada, the European Union, Norway and Australia.

It is early for drawing conclusions about the consequences of this radical move. The first result is extremely sharp price increases on the weekly level for foodstuffs like chicken $(1.4 \%)$, pork $(0.9 \%)$, frozen fish $(0.5 \%)$ and cheese $(0.4 \%)$. The retail price for apples rose by 0.5 percent every week (Russian State Statistics Service - ROSSTAT). 


\section{THE EFFECTS OF RUSSIA'S ACCESSION TO THE WTO ON THE WORLD TRADE FLOWS OF AGRICULTURAL PRODUCTS}

Countries exporting agricultural and food products to Russia should realize significant benefits from Russia's accession to the WTO due to reduced tariffs, trade facilitation, the predictability of foreign trade and transparency of the Russian non-tariff measures for trade regulation. This would be a great relief to exporters to the Russian market, given that previous trade was often exposed to the capricious procurement cancellations as well as changes in tariffs and rules by Russia.

The average rate of tariff protection on agricultural and food products in Russia was not particularly high even before the accession to the World Trade Organization, so that enormous increase in exporting countries' income is not expected either. However, for several product groups it could almost certainly have been argued that the new rules would significantly boost exports to Russia. That referred to the products which RF imported in large quantities - sugar, meat, fruits, milk and dairy products, tea and coffee. The countries that export these products to Russia should have realized enormous gains from huge Russian economy's entering the WTO.

Russian Federation had the largest import of meat from Canada, Brazil, which is a major exporter of pork and beef and sugar to the Russian market, other countries of Latin America, Uruguay, Argentina and Paraguay, the U.S. and some EU countries, especially Germany. The import of meat in recent years, along with the strengthening of domestic production, has constantly been decreasing, but it was expected that with the Russia's accession to the WTO this market would be conquered again. However, Russia introduced a ban on imports primarily from the United States in February 2013, then the EU, followed by Latin American countries several months later, thus closing itself down for an unlimited period to these parts of the world.

The U.S. expected a significant increase in exports in RF. The U.S. is very interested in the huge Russian market, and is one of the largest suppliers of the Russian meat market. After the ban on the pork, beef and turkey imports from the United States, under the pretext of the ractopamine $^{3}$ protection, the U.S. exports to Russia dropped almost to zero, i.e. far below the level reached before Russia's entering the WTO. This also applies to Brazil and other Latin American countries.

\footnotetext{
${ }^{3}$ A substance by which domestic animals are treated and which has scientifically been proven to be harmless, but it is still banned in some 160 countries, including the EU, China and Russia.
} 
Similarly, on February 4, 2013 Russia introduced a ban on the import of frozen poultry, beef and pork from Germany, also for failing to meet health and sanitary conditions. Since March 20, 2012 a ban has been introduced on imports of live pigs to Russia from the European Union, including Germany. Later, the law has been expanded to the protein livestock feed. The law has supposedly been introduced due to numerous epidemics in the EU countries caused by a Schmallenberg virus and a large dispersion of Blutung viral disease. Although the EU has more opportunities to realize its interests in Russia than through trade in agricultural products, and that primarily refers to setting up of European companies in Russia which is currently being implemented on the basis of the most favored nation treatment, this ban has had a very negative impact on individual countries. All of these bans are exceptions allowed by the rules of WTO. According to Legal text GATT 1947, Article XX „Subject to the requirement that such measures are not applied in a manner which would constitute a means of arbitrary or unjustifiable discrimination between countries where the same conditions prevail, or a disguised restriction on international trade, nothing in this Agreement shall be construed to prevent the adoption or enforcement by any contracting party of measures... (b) necessary to protect human, animal or plant life or health".

As far as Russia's largest trade partners from the region - Belarus and Kazakhstan, is was not expected that the entry of Russia into the WTO would have direct impact on their mutual trade, since it is regulated by the Customs Union Agreement. Other CIS countries as well have different agreements with Russia that regulate their mutual trade. However, by various restrictions imposed by Russia on imports of agricultural products of developed countries some 'space' opens up for products from CIS countries. These statistics may not be of great importance for Russia, which is planning to achieve relative selfsufficiency in terms of agricultural production, but for the underdeveloped economies of the post-Soviet space this may represent significant benefits.

Another trade route may experience a positive trend and that is the export of developing countries to the markets of the Customs Union. Lifting of Russian restrictions on access to its agricultural and food market will lead to a reduction in tariffs in other countries of the Customs Union. In this way developing countries will be given easier access to not only Russian, but also Belarusian and Kazakh markets. 


\section{CONCLUSION}

Russia's admission to the WTO, as the largest and most powerful economy and politically crucial entity in this region,

1. has shown certain specifics compared to other member states,

2. has had a much wider significance than the national one,

3. has achieved effects contrary to all forecasts.

1. The entry of Russia into the WTO was specific primarily due to the length of the very process of 19 years, which is far longer than the admission process of any current member of the organization. Another specificity related to the first one referred to the more favorable conditions under which it was admitted to the WTO than those prescribed by the standards of the organization and applicable to other member countries. The negotiations lasted for nearly two decades because Russia approached them extremely seriously, with persistency to achieve its goals, and with strategic skills thanks to which it managed to obtain better starting conditions. RF approached the implementation of the agreement in the same way preventing thus numerous expected adverse effects.

2. Given the limited ability to support agriculture that interferes with trade, and the inability of the Russian government to raise tariffs above the threshold level, the expectations were that Russia would for a long time be dependent on imports of livestock products. The countries exporters of meat, especially beef, in the Russian market expected very positive effects of Russian accession to the WTO. In terms of export of these products, all suppliers of the Russian market from North and Latin America and the European Union, instead of the expected growth, experienced a decline in exports even during the first year upon Russia's accession to the WTO. Given the size of the Russian market, this has had a significant negative impact on some of these agricultures.

The assumption that trade relations with Russia upon its acceptance of the WTO rules would become simpler, more transparent and easier for export partners proved to be naive. In fact, it appears that they have become more complex.

3. The effects of Russia's acceptance to the WTO on Russian agriculture in the most important segments are completely contrary to expectations and forecasts.

Owing to the aforementioned 'skills', i.e. bypassing the obligations provided for by the WTO membership, in both these ways, Russian livestock sector, the forecasts of which were quite pessimistic, continued the rise that had started several years before the WTO accession. 
On the other hand, the production of grains, especially wheat is the sector that had the best chance to prosper due to the WTO accession. Positive forecasts on that were given bearing in mind that Russia had been a great producer and an important exporter even before that, and that free access to others, especially wealthier markets would enable easier and bigger export. However, neither the production nor export of grains has increased; on the contrary they have decreased.

Pessimistic forecasts of Russian analysts were completely true for the sector of milk and dairy products, which experienced a tremendous increase in imports of $20 \%$ to over $30 \%$. This is a sector in which the planned allocations from the 'Green box' were much lower than for livestock, while sanitation services did not have the grounds to ban the import. Therefore, this exactly shows what would have happened with the rest of the Russian agriculture if the WTO standards had been fully applied.

Owing to a well thought out and realized strategy Russian agriculture on the whole has not experienced particularly negative effects of the admission to the WTO, as Russian experts and politicians feared, but we cannot speak about any benefits either. It is not only that a year and a half is a short period in order to feel positive effects; the World Bank and the very WTO often emphasize that it takes several years for the positive effects to be felt. This may refer to certain segments of the economy of a country, an industry, foreign investment, modernization, improvement of business conditions, but agricultural production which has for several years been influenced by far stronger competition, has little chance of recovery.

Membership in the WTO remains an unavoidable path to the intensive involvement in the global economy, but the example of Russia shows that only those member countries and only those sectors of the economy prosper in which its rules are successfully bypassed. 


\section{LITERATURA}

1. Bilharinho, C, Larkin, B, (2013), Red Meat Market ReportRussia, MLA Market Information

2. Bloomberg, http://www.bloomberg.com/news/2012-01-31/porkimports-into-russia-may-triple-on-wto-accession-union-says.html (21.1.2014)

3. Cooper,W.H. (2012) Russia's Accession to the WTO and Its Implications for the United States, Congressional Research Service

4. Erokhin V, Ivolga, A. (2013), New developments in Russia-EU trade with agricultural goods: influences of trade integration, Economics of Agriculture 2/2013

5. FAO, Food Outlook (2012) www.fao.org/fileadmin/templates/est/meetings/wto_comm/Trade_ Policy_Brief_Russia_final.pdf (05.02.2014)

6. FAOSTAT,http://faostat.fao.org/CountryProfiles/Country_Profile/ Direct.aspx ?lang=en\&area $=185(05.02 .2014)$

7. Federalna statistička služba Ruske federacije, http://www.customs.ru/ (15.03.2014)

8. Global Counsel (2013), Russia in the WTO: one year on, London

9. International Trade Centre -ITC, (2012), Russia's Accession To The Wto: Major Commitments, Possible Implications, SaintPetersburg University, Economics Faculty

10. Karlova, N. (2013), Factors Contributing to the Decrease of Prices For Pork and the Decline of Pig Production Profitability, Russian Economic Developments No. 8, Moskow

11. Kiselev, S, Romashkin, R. (2012), Possible Effects of Russia $\square s$ WTO Accession on Agricultural Trade and Production, ICTSD, Geneva

12. United States Department of Agriculture, Grain: World Markets and Trade, January 2014 http://apps.fas.usda.gov/psdonline/circulars/grain.pdf (15.01.2014)

13. United States Department of Agriculture, http://apps.fas.usda.gov/psdonline/psdHome.aspx (15.01.2014)

14. Vassilieva Y. (2012), Agriculture Development Program 20132020, USDA, http://gain.fas.usda.gov/Recent\%20GAIN\%20Publications/Agricu lture\%20Development\%20Program\%2020132020_Moscow_Russian\%20Federation_11-6-2012.pdf 
15. WTO (2014)www.wto.org/english/news_e/news11_e/acc_rus_10nov11_e.htm (15.02.2014)

16. WTO, Legal text GATT 1947, Article XX, http://www.wto.org/english/docs_e/legal_e/gatt47_02_e.htm (24.09.2014)

Рад је примљен: 23.05.2014.

Рад је прихваћен за штампање: 26.09.2014. 